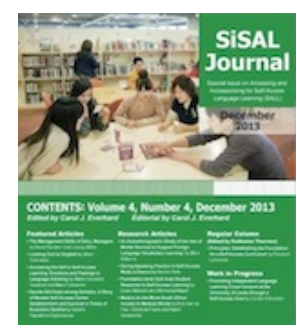

ISSN 2185-3762

Studies in Self-Access Learning Journal

http://sisaljournal.org

\title{
Looking Out for English
}

Brian Tomlinson, Leeds Metropolitan University, U.K. \& Annaheim University, U.S.A.

Corresponding author: brianjohntomlinson@googlemail.com

Publication date: December, 2013.

\section{To cite this article}

Tomlinson, B. (2013). Looking Out for English. Studies in Self-Access Learning Journal, 4(4), 253-261.

\section{To link to this article}

http://sisaljournal.org/archives/dec13/tomlinson

This article may be used for research, teaching and private study purposes.

Please contact the authors for permission to re-print elsewhere.

Scroll down for article 


\title{
Looking Out for English ${ }^{1}$
}

Brian Tomlinson, Leeds Metropolitan University, U.K. \& Annaheim University, U.S.A.

\begin{abstract}
Coursebook activities tend to neglect three vital prerequisites for effective language acquisition i.e. language experience, language discovery and language use. They tend to focus on providing instruction, exemplification and practice in the classroom, and they do very little to encourage learners to achieve language experience, discovery and use outside the classroom. In this article I propose "new ideas' for materials which help learners to gain language experience, language discovery and language use both inside and outside the classroom.
\end{abstract}

Keywords: language instruction, language practice, language experience, language discovery, language use

'Nearly $100 \%$ of innovation - from business to politics - is inspired not by "market analysis" but by people who are supremely pissed off by the way things are.' (Gay, 2009).

In the world of EFL materials development I'm 'supremely pissed off' with at least two things. Recently in Tomlinson and Masuhara (2013), an ELT Journal review, we investigated six current global coursebooks for adults and confirmed our impression that:

1. EFL coursebook activities tend to neglect three vital prerequisites for effective language acquisition i.e. language experience, language discovery and language use. Instead they tend to focus on providing instruction, exemplification and practice in the classroom.

2. EFL coursebooks make very little attempt to stimulate or help their users to experience or use English outside their classroom. And yet it's

\footnotetext{
1 This article is to be published in Folio 16/1, in January 2014. It is reproduced here with the kind permission of the author, Brian Tomlinson and of Folio editor, Freda Mishan. Folio is the journal of MATSDA (the Materials Development Association) which highlights issues in the field of materials development for language learning. Founded in 1993, MATSDA is an international association which brings together teachers, researchers, materials developers and publishers in a joint endeavour to make language learning materials as effective as possible. For more information, go to www.matsda.org
} 
indisputable that no classroom course can provide enough English to lead to sufficient acquisition for most of its learners (see Barker, 2011; Fukuda \& Yoshida, 2013). Learners need to look out for English outside the classroom, as I found, for example, from a study of intermediate learners at Bell College, Saffron Walden which revealed that the only ones who improved their communicative competence over a term were the ones who found English outside the classroom by reading newspapers, watching tv, going to the cinema, joining clubs, going to the pub and, most importantly, talking to people in English.

My new 'innovation' consists of a proposal for a course called Looking Out for English which:

1. uses an EDU approach (i.e. Experience/Discovery/Use) to provide engaging experience of English, to stimulate learner discovery and to give opportunities to use English for communication (see Tomlinson, 2013b for a theoretical justification of these three requisites for durable acquisition).

2. provides activities which aim to achieve the objectives in 1 above both inside and outside the classroom.

\section{Activities in Looking Out for English}

I'd like to stress the point again that the activities are for use both inside and outside the classroom and the intention is that the users of the course will spend far more time acquiring English outside the classroom than learning it inside the classroom. Here are some examples of EDU activities:

\section{For Providing Engaging Experience of Language in Authentic Use}

1. Task free activities (using extracts in the classroom from books, magazines, comics, newspapers, the web, YouTube, TV, adverts, films, the radio, etc. which can be followed up outside class time).

These activities involve the teacher (at the beginning or end of a lesson) 'performing' or presenting a potentially engaging authentic text (e.g. a poem, a story, a newspaper article). Those students who were engaged take a copy of the text, experience it again outside the classroom and decide whether to follow up its suggestions for finding and experiencing similar texts outside the classroom. 
2. Engaging extensive experience of English in the classroom which can be continued outside of class time (e.g. books, magazines, comics, newspapers, the web, YouTube, TV, films, the radio, DVDs, etc.).

Kanda University in Japan provides such opportunities in the classroom and then provides access to a self-access centre rich in potentially engaging extensive texts. A teacher in Jakarta achieved the same thing, without expense, by encouraging her students each week to take something to read from the class library box and to bring it back, together with a new engaging 'text' they had found for themselves. A teacher in Japan did something similar by getting her students to take home a student-recorded text each week and to bring another newly-recorded one as well when they brought it back.

I've done it by getting students to select a section from a newspaper to read (e.g. film reviews) and then getting them to write a summary of it (and of the same section from other newspapers) for the class newspaper. I've also done it by getting students in Oman to predict what was going to happen in a football match in the Premier League in England and then to watch the match (with an English commentary) on TV that night.

3. Text-driven units of material which start with readiness activities which activate the learners' minds in readiness for extensive experience of a written or spoken text in the classroom.

After doing response, discovery and development activities in relation to this text the students are encouraged to read further related texts both provided for them and found by themselves. On Target (1994) in Namibia, English for Life (Tomlinson, Hill \& Masuhara, 2000) in Singapore and Searching (Fenner \& Nordal-Pedersen, 2010) in Norway, are examples of coursebooks which use this approach. See Tomlinson $(2003,2013 a)$ for a detailed description of a text-driven approach.

\section{Making Discoveries about How the Language is Typically Used}

1. Research tasks which start in class and continue outside it.

An example of this was an activity I gave a class in which half the students were the 'some' group and half were the 'any' group. Each group had to find as many examples of their determiner in use in texts I gave them and to put these 
examples together to constitute the beginnings of a corpus. For homework, they expanded their corpora from texts they found for themselves and then in class they made and shared generalisations about the functions of the two determiners (for example that 'any' is typically marked while 'some' is typically unmarked).

Another example was showing a class a video of a British chef getting two celebrities to help him make a chocolate cake, getting the students to make discoveries about the language the chef used to get people to help him and then getting them to find out if this was typical or idiosyncratic by watching TV programmes in which somebody was getting other people to help them (see Tomlinson, 2010).

2. Self-access discovery tasks making use of the environment.

For example, in class I got students to work out the meaning of a sign in Bahasa Indonesia by describing how I made discoveries which helped me. The sign was:

Table 1. Indonesian road sign

Mobil Cuci
Air Panas

I told the students that I saw this by the side of the road when I was stuck in a traffic jam in Jakarta. Every day I passed it and I eventually worked out its meaning after noticing many cars were parked near it and then discovering that washbasins in restaurants always included the word 'cuci' in notices above them, seeing that bottles of water in a supermarket all included 'air' on the label and being asked by a waitress if I wanted it 'panas' or 'padas' when I asked for the food to be hot. Once the students had worked out that the sign was advertising a car wash with hot water, I encouraged them to look out for signs in English which they did not understand and then to find ways of working out the meaning for themselves.

3. Blooper activities leading to exploration of the English in the environment.

A sample of amusing and authentic bloopers are collected from the web or from books and presented to the learners who then have to spot the errors and 
work out what should have been written. Here are a few examples (see Table 2) taken from advertisements and published in (Hill, 2011):

Table 2. Bloopers

1. Crash Courses available for those wishing to learn to drive very quickly.

2. TIRED of cleaning yourself? Let me do it for you.

3. DECORATOR Specialises in inferior work. Immediate attention. Estimates free.

4. Gentlemen

Drop Your Trousers

Here for Overnight

Service

The learners share their solutions and are then given a week to collect bloopers in English from their own environment. A week later, the learners in groups put their bloopers together and then present them to other groups to correct. The learners not only gain experience of English from the bloopers but from all the English they look at to find them. In many environments they can also become much more aware of how much English is available to them outside the classroom.

4. Text-driven units of material which include discovery activities involving focused exploration of a text in class followed by related research outside of class.

For example the learners could be given the expression 'In case of fire' and asked in groups to decide where they are likely to see this and what its functions are. The teacher then performs the poem 'In case of fire break glass' by Roger McGough (McGough, 2004 ) and asks the learners, 'Did you like the poem or not. Why?' after discussing their answers, groups of learners use the poem to make generalisations about the form and the functions of 'In case of' expressions. They are then given a week to collect authentic examples of 'In case of' expressions before being asked to put together an 'In case of' corpus and to make final conclusions about form and functions. They then write bizarre 'In case of' notices to put around the school (e.g. 'In case of learning jump for joy'; 'In case of fire carry on sleeping'). 


\section{Using the Language for Communication}

\section{Unstructured learner interaction}

The learners form a social English club and agree that whenever they meet outside the classroom they will talk to each other in English. They also agree that they will look out for opportunities to introduce their fellow club members to English (e.g. by introducing them to English speaking friends; by letting them know about a drama which is going to be performed in English). For an example of a very successful experiment in encouraging unstructured interaction in a Japanese university, see Barker (2011).

\section{Writing booklets about enthusiasms}

Each learner tells the teacher about their favourite enthusiasm and the teacher helps them to work out a list of contents for a booklet on this enthusiasm. She also helps them to decide where to find further information about it outside the classroom. The learners spend a number of weeks inside and outside the classroom writing their booklets (using the teacher as a resource when needed). The learners write an illustrated draft of their booklet and this is then monitored, first of all by a fellow learner and then by the teacher. The final version is then 'published' and the learners read each other's booklets in class and outside of class.

One of my MA students used this approach with elementary level adult learners in London and very impressive booklets were produced (e.g. about restoring antique furniture and about growing vegetables on an allotment).

\section{Writing a novel}

The learners are told to visualise a scene from their home town or village and to see somebody interesting that they know there doing something interesting. They then write a description of what they can see in their minds and this becomes the first page of their novel. They then spend time inside and outside class writing their novel and using their fellow learners and teacher as resources when needed. They also read 'novels' outside the class for inspiration. When their novels are finished they are monitored by other learners and by the teacher and then 'published' for other learners to read. 
I used this approach with a class of unmotivated lower intermediate learners in Vanuatu and after ten weeks of writing they each took a 60-80 page novel home to their villages. They also took self-esteem and pride, as well as a muchincreased competence in English.

\section{Writing a soap opera}

The teacher leads a class discussion on soap operas in which opinions are expressed about what a soap opera is, what its typical characteristics are and what makes a good soap opera. The learners, in groups, then come up with a title and characters for a soap opera set in the vicinity of their school. They vote for the best suggestions and the winning group are given the task of writing and recording the first five minutes of the soap opera. A week later, the recording is played to the class and another group is given the task of writing and recording the next five minutes. Each week, a group writes and records and at the end of the term each learner is given a copy of the complete recording. During the term, all the students are encouraged to watch soap operas in English and to go out into the local area and find out as much as they can about it.

I used this approach with a group of upper-intermediate Argentinian students in a small town in England and each group was so determined to succeed that they started asking local people for information and advice and to monitor their scripts for them. This out-of-class interaction was a great bonus, in addition to the increased confidence, competence and self-esteem that they gained.

\section{Projects}

The students are given projects which involve them going outside the classroom to interview people, to research local institutions and to attend local functions. They then compile the information they have gained and present it in the form of a mock TV documentary to the class (and then maybe the whole school).

Examples of such projects would be 'The Expatriate Community in Istanbul', 'Supporters of English Football Teams in Jakarta' and 'English Food in Tokyo'. 
6. Text-driven units of material which include development activities which involve the learners in writing texts related to the core text of the unit (e.g. continuations, prequels, sequels, different narrator, etc.).

An example of this is when I used Roald Dahl's poem The Three Little Pigs (Dahl, 1984) as the basis of a text-driven lesson. One of the activities was for the learners to write a short story about Little Red Riding Hood in their town (she's the main character in the poem). Another activity was to listen to and read the True Story of the Three Little Pigs (Scieszka, 1991) and then decide what they think really happened. Some of the learners then pose as journalists, they interview learners acting as the wolf, the pigs and Little Red Riding Hood and then groups use the interview scripts to write an article called 'What Really Happened to the Three Little Pigs'. The learners are then encouraged to find and share other versions of the story of the Three Little Pigs (there are many poems, stories and songs based on the story).

\section{Conclusion}

My conclusion is simple. Materials should stimulate and help learners inside the classroom to acquire English outside the classroom.

\section{Notes on the contributor}

Brian Tomlinson is a Visiting Professor at Leeds Metropolitan University and a TESOL Professor at Anaheim University. He has worked as a teacher, teacher trainer, curriculum developer, football coach and university academic in Indonesia, Japan, Nigeria, Oman, Singapore, UK, Vanuatu and Zambia and has given presentations in over sixty countries. In 1993, he founded MATSDA (the international Materials Development Association) and he is now President of the association. His many publications include Discover English (with Rod Bolitho), Openings, Materials Development in Language Teaching, Developing Materials for Language Teaching, Research for Materials Development in Language Learning (with Hitomi Masuhara), Blended Learning in ELT: Course Design and Implementation (with Claire Whittaker) and Applied Linguistics and Materials Development. 


\section{References}

Barker, D. (2011). The role of unstructured learner interaction in the study of a foreign language. In S. Menon \& J. Lourdanathan (Eds.), Readings on ELT materials, $I V$ (pp. 50-71). Petaling Jaya, Malaysia: Pearson Longman.

Dahl, R. (1984). The three little pigs. In R. Dahl (Ed.), Revolting rhymes (pp. 4147)._Harmondsworth, UK: Puffin.

Fenner, A., \& Nordal-Pedersen, G. (2006). Searching, 8. Oslo, Norway: Gyldendal.

Fukuda, S. T., \& Yoshida, H. (2013). Time is of the essence: Factors encouraging out-of-class study time. ELT Journal, 67(1), 31-40. doi:10.1093/elt/ccs054

Gay, T. (2009, September 15). Re: Must be a mis-quote [Web log comment]. Retrieved from http://www.tompeters.com/dispatches/011241.php

Hill, H. (2011). Harry Hill's bumper book of bloopers. London, UK: Faber and Faber.

McGough, R. (2003). In case of fire break glass. In R. McGough, Collected poems. London: Penguin.

Ministry of Education (1994). On target. Windhoek, Namibia: Gamsberg Macmillan.

Scierszka, J. (1999). The true story of the three little pigs. Harmondsworth, UK: Puffin.

Tomlinson, B. (2003). Developing principled frameworks for materials development. In B. Tomlinson (Ed.), Developing materials for language teaching (pp. 107-129). London, UK: Continuum.

Tomlinson, B. (2010). Helping learners to fill the gaps in their learning. In F. Mishan \& A. Chambers (Eds.), Perspectives on language learning materials development (pp. 87-108). Berlin, Germany: Peter Lang.

Tomlinson, B. (2013a). Developing principled frameworks for materials development. In B. Tomlinson (Ed.), Developing materials for language teaching ( $2^{\text {nd }}$ ed., pp. 95-118). London, UK: Bloomsbury.

Tomlinson, B. (2013b). Second language acquisition and materials development. In B. Tomlinson (Ed.), Applied linguistics and materials development (pp. 11-30). London, UK: Bloomsbury.

Tomlinson, B., Hill, D. A., \& Masuhara, H. (2000). English for Life, 1. Singapore: Times Media.

Tomlinson, B., \& Masuhara, H. (2013). Adult coursebooks. ELT Journal, 67(2), 233-249. doi:10.1093/elt/cct007 